\title{
Investigating the relationship between God and man in the tragedy of Attar and Haft Aurang Jami
}

\section{Investigando la relación entre Dios y el hombre en la tragedia de Attar y Haft Aurang Jami}

\section{Zahra Ghezelsofli}

PhD Student in Persian Language and Literature, Islamic Azad University, Mashhad Branch, Iran

\author{
Akbar Shabani \\ Member of the Department of Persian Language and Literature, Islamic Azad \\ University, Mashhad Branch, Iran

\section{Mohammad Fazeli} \\ Member of the Department of Persian Language and Literature, Islamic Azad \\ University, Mashhad Branch, Iran
}

Received 10-08-20 Revised 12-10-20

*Correspondence

Email: ZahraGhezelsofli@gmail.com
Accepted 09-21-21 On line 03-04-21

\section{Cite as:}

Ghezelsofli, Z., Shabani, A., \& Fazeli, M. (2021). Investigating the relationship between God and man in the tragedy of Attar and Haft Aurang Jami. Propósitos y Representaciones, 9(SPE2), e1082. Doi: http://dx.doi.org/10.20511/pyr2021.v9nPE2.1082 


\section{Summary}

Man, God and their relationship with each other is one of the most fundamental topics in mystical literature. Mystical poets, as the possessors of the gentle and sensitive divine spirit, have included the relationship between God and man in the form of grace and pleasantness, which has become one of the deepest phrases of their works. This study has examined the relationship between God and man in a library and in a comparative way in the tragedy of Attar Neyshabouri and Divan Jami. The purpose of this study is to investigate the relationship between God and man based on the basic human principles of help, guidance and love ... which shows that the relationship between God and man is one of the important concerns of these two mystics and they have different ways and factors to achieve It has provided; The most important results obtained from this research are that the works of Attar and Jami are full of the manifestation of the relationship between God and man, and this relationship is sometimes quoted from the language of the poet and sometimes from the language of fictional characters. The recklessness, boldness and intimacy that exist in the poems of these two have given a special depth to their verses that give the reader a feeling of tenderness and the peak of servitude, while the loving relationship of God has been the highest type of relationship.

Keywords: Communication, God, Man, Attar, Jami.

\section{Resumen}

El hombre, Dios y su relación entre sí es uno de los temas más fundamentales de la literatura mística. Los poetas místicos, como poseedores del espíritu divino dulce y sensible, han incluido la relación entre Dios y el hombre en forma de gracia y agrado, que se ha convertido en una de las frases más profundas de sus obras. Este estudio ha examinado la relación entre Dios y el hombre en una biblioteca y de forma comparativa en la tragedia de Attar Neyshabouri y Divan Jami. El propósito de este estudio es investigar la relación entre Dios y el hombre basado en los principios humanos básicos de ayuda, guía y amor ... lo que demuestra que la relación entre Dios y el hombre es una de las preocupaciones importantes de estos dos místicos y ellos tener diferentes formas y factores para lograrlo lo ha proporcionado; Los resultados más importantes obtenidos de esta investigación son que las obras de Attar y Jami están llenas de la manifestación de la relación entre Dios y el hombre, y esta relación a veces se cita del lenguaje del poeta y otras del lenguaje de personajes de ficción. La imprudencia, el atrevimiento y la intimidad que existen en los poemas de estos dos han dado una profundidad especial a sus versos 
que le dan al lector un sentimiento de ternura y la cima de la servidumbre, mientras que la relación amorosa de Dios ha sido el tipo más alto de relación.

Palabras clave: Comunicación, Dios, Hombre, Attar, Jami.

\section{Introduction}

The relationship between God and man has a special place in the works of writers and poets. Shahid Motahari believes, "In Islam, everything revolves around God, both in terms of the purpose of the resurrection of the prophets and the purpose of a person's life ... that people are invited In order to get acquainted with God and the prophets are the link between the creature and the Creator and the link between them "(Motahari, 1351, pp. 1312).

Jung, in his book Psychology and Religion, refers to this connection in a way: "When Gilgamesh summons the gods in the Babylonian epic with great arrogance, the gods also summon the man who, in terms of strength, Gilgamesh equates, invents and creates in order to put an end to the blasphemous ambition of this hero "(Jung, 1991, p. 25)

James also believes in the book "Religion and Psyche": "Religious people generally accept that every event and thing that is related to their lives, in their opinion is a reflection of divine providence" (James, 2008, p. 168) .

"The great system from which all the forces of the world and even the whole world are the force of matter, the system which man sometimes calls the system of creation, once called the supernatural, the unseen world, the system of divinity, God; If someone got acquainted with it, got in touch with it, made a deal with it and benefited from it, it is impossible for another force, power, position of other things to attract him "(Ibid., 2008, p. A)

Mohammadi Reyshahri believes, "If the human eye does not have a hijab and the obstacles of intellectual and heart cognition have not blocked the mind and heart, he will see God in everything he looks at. In the mirror of the earth, the mountain, the desert, the sea, the trees, and in everything, the seer sees the sight of God "(Mohammadi Reyshahri, 1996, p. 83).

Persian language poets have also paid special attention to this issue, for example, Attar, Hafez and Rumi have mentioned this connection many times in their works.

Rumi considers God to be the first and the last of the world and believes that God is in contact with man through all the particles of the universe:

O giver of intellects, cry out until you want, no one wants you

Asking for the test and who is our goodness, you are the first, you are the last 
(Rumi, 1379: 6 / 1440-1438)

Attar mentions this connection well in his tragedy letter:

He said: I came to you, guide, to tell me what God says

What did you see badly when you took refuge in a place other than ours? ...

If I do not imprison you for a few years, not God Almighty!

(Tragedy, Section 37)

\section{Research objectives}

The relationship between man and God is one of the topics discussed among poets and writers, and the only difference between their worldviews is related to the role and impact they have on God and man in the system of existence.

The purpose of this study was a comparative study of the relationship between God and man from the perspective of Attar and Jami, so that with a deep understanding and understanding of it, the field of spiritual relations can be placed on human beings to conquer the peaks of spiritual perfection and The horrible whirlpools of absurdism have been spared and he should face his problems with the knowledge of the Creator's relationship with him, and since the poets of Persian literature have a special view on this subject, it has always been fascinating for the researcher to know from the point of view. Attar and Jami, what kind of relationship is intended for God and man, and no doubt, the more the dimensions of the mystics' views on this issue are determined, the more beneficial it will be for human society and the way for people who have distanced themselves from the truth and God. Smoothes.

\section{Research questions:}

Each research seeks to answer the research questions and hypotheses that it seeks to answer by collecting material and describing and analyzing it. In this article, questions about the subject are raised, which are:

What is the relationship between God and man from the point of view of Attar and Jami? What is the main way of communication between God in the works of two poets? What are the aspects and aspects of the God believed by the two mystics compared? In what aspects and aspects is the human being in the works of the two poets related?

\section{Research background}

So far, many articles have been published about the relationship between God and the world and man, and in addition to this research, the views of mystics have also been 
mentioned; Including this $m$ Articles on the relationship between God and man in the theological and mystical literature with emphasis on the works of Rumi (2012), the God of Existential Unity and the images derived from it in the works of Attar (1398), the pattern of revelatory communication (2012), The type of relationship with God (1393), me and you (1378), non-linguistic relationship between God and man by Toshiho Ko Izutsu (1348), the relationship between man and God from Rumi (1396), the relationship between God and man; Representation, incarnation or manifestation? (2012) and (Popp, Luborsky, Andrusyna, Cotsonis, \& Seligman, 2002).

In the meantime, what is obvious is that the lack of study of the relationship between God and man by researchers is comparative in the poems of poets such as Attar and Jami. Therefore, this study examines this issue by asking a research question about how God and man relate from the perspective of Attar and Jami.

\section{Research method}

The method of data collection in this research is descriptive and content analysis; Thus, first by studying the poems of these two poets and then the descriptions of their works and using books, magazines, publications and treatises related to the subject of research in this field has been used. The topics of filing are then categorized and the topics are categorized and analyzed thematically, and finally the article is compiled and written.

\section{Fundamentals of research}

\section{The meaning of the word communication, God and man}

The concept of communication in the present article is the ontological relationship between God and man on the one hand and the inseparable link between the two on the other hand. In The Me and You, Martin Buber describes the relationship between God and man as follows:

"The fact that you need God more than anything else is always on your mind, but does God really need you in His eternal abundance? If God did not need man, how could man continue to live? You need God to be you, and God needs you for all that your concept of being ... The world is not a divine playground, it is a divine destiny ... Creation passes over us. He becomes one with us, transforms us, fascinates and intoxicates us, then we surrender, participate in creation, face creation, and offer ourselves to him as helpers and companions. (Buber, 1398, p. 131)

Soroush in his book "Tradition and Secularism" has studied God, the concept of God is one of the most important categories of human life. Man has always been faced with this concept in all situations, whether alone or in the heart of social life, or as a religious or 
atheist. This concept is rooted in human thought, and various civilizations, cultures, and religions influenced by the concept of God have emerged in human history. (Soroush, 2002) Tivarai has also referred to this concept in his book "Comparative Theology" and says: God in Islam is the only creator and destroyer of all phenomena. God is omnipresent, and although human attributes such as hearing, sight, etc. are used to describe him, he should not be thought of as human. It is eternal and in creation. He created the world and keeps it constantly changing. The presence of God is felt everywhere in the world. God is a mysterious being who introduces himself to human beings through his prophets. The judge is all good and bad. (Tiwarai, 1381: 183-197).

Paying attention to human beings and studying them is not a new phenomenon and has an ancient history. It has been considered by various religions, schools and cultures since ancient times. One surah of the Holy Quran, Surah 76, is named after man. Man also has a high status in Islam, and "In many verses of the Holy Quran, God Almighty expresses the honor and dignity of man. "In some verses, man is honored by God." (Khorramshahi, 1998: 306)

In the twenty-eighth chapter of the tragedy, Attar deals with man or man. The seeker of thought goes to a person on the twenty-eighth house of his journey and talks to him:

Confidence in the words and sight of the Ima

(Attar, 2007: 348)

\section{God's relationship with man}

God is in contact with all human beings, but this connection is not the same for different human beings, but according to the situation and time of each individual. This relationship and the view of the essence of truth in the poems of Attar and Jami is not the same as man, but the conditions of individuals have a direct role in the type of relationship between God and man, so that the relationship is sometimes in the form of the Creator helping man and sometimes with love and sometimes anger. Or through guidance and generosity, people are addressed to God.

\section{Helper and helper}

One of the concepts found in the works of Attar and Jami in the relationship between God and man is the concept of God's helper in this relationship. Helper means helpful, helper, assistant, supporter, helper. This finding is consistent with the results of a study conducted by Popp, Luborsky, Andrusyna, Cotsonis, \& Seligman, 2002 (), because in that study was also the concept (Protective and Helpful) in the relationship between God and man. . 
God supports the oppressed and does not allow anyone to trample on their rights. In this view, the Lord punishes the oppressors for their evil deeds in various ways and fulfills the ideal desires of the oppressed. When man finds himself incapable of confronting oppressive rulers and rulers and cannot defend his rights against them, he creates such ideas to appease himself. You can find examples of this kind of ideas in the works of Attar and Jami Half. Stories in which God severely punishes even powerful kings. We see another example of this kind of idealistic perception in the anecdote of the tragedy. There we read that one day, when Abdullah Tahir was returning from hunting on a bridge, Pir Zali suddenly jumped out of a corner to give him a letter. This old woman caused Abdullah's horse to fall and his hat to fall off his head. Abdullah became very angry and asked him, "Who are you and what are you doing here?" The old woman handed him a complaint saying that my son was being held in your prison. O Amir! Please release him from prison, because my pain burns and my days are dark. Have mercy on my old age and burning heart! But Amir, who was very angry, swore that he would not release his son until he was imprisoned. Hearing this, the old woman sighed and moaned and went to heaven and frightened Abdullah of a God who has everything in his hands and he is able to do anything:

If you are also capable of doing something, God is all-knowing and all-knowing Now I leave my work with him, you go, I also took my burden

It was free to come to you because it was the right of the world.

I hit you, I was burnt, I went to your place, are you better now or God?

(Attar, 1388: 18)

The old woman's words, which also reflected the burning inside her, deeply affected Abdullah and changed his situation. Then, while shedding bloody tears, he swore that he would not cross the bridge until the old woman's son was released from prison and handed over to him right in front of his eyes; Finally, the boy was released and handed over to his mother. Attar continues:

He disgraced him and told him to build it in his hometown so that they could return it So they preach from the left and right of Cain, the way of God, the free of God

(Attar, 2007: 118)

Attar says after these verses that this was done against the will of Abdullah and the will of God. If you wait, you will find the Lord better than kings. 
Someone asked Imam Ali (AS): "Is there any other revelation besides the Qur'an?", Imam replied that there is no revelation other than the Qur'an; But the Lord gave His friends an understanding like revelation to help them:

He said that there is no revelation except the Qur'an, but he gave his friends a good understanding

To the understanding that he spoke as a revelation in his words to speak the truth

(Attar, 1386: 57)

By the right, I do not love you in all my work and work.

(Jami, 1366: 250)

Our help is not for the purpose

(Same)

What a happy time and day when help came from connecting help

Light up the light of acquaintance to get rid of the heat somewhere

(Same)

Praise be to God that the government helped us

(Same)

\section{Love}

One of the other concepts we discussed in this article is God's love for His servants. Love means "extreme love, excessive friendship, total love, and excessive enthusiasm." (Moein, 1382: 1591) The main concept of love is self-sacrifice, preferring others to oneself, self-sacrifice and making happy.

The findings of this study were consistent with the findings of studies (Kapogiannis, Barbey, Su, Krueger, \& Grafman, 2009; Kapogiannis, Barbey, Su, Zamboni, et al. 2009; Kendler et al. 2003) in which studies The concept (Love) was also expressed in the relationship between God and man.

Jung also believes in the book "Psychology and Religion": "The truth of love is the perfection of laws, because it includes decency, goodness, justice and mercy" (Jung, 1991, p. 164)

James in his book "Religion and Psyche" believes: "We should know God as a father who looks at us with a loving gaze in the sky" (Corbett, 1393: 11)

Your love is broken The prosperity of the world is broken Love is broken on your back (Attar, 1386: 56)

We got drunk from the ruins of love

(Ibid: 495) 
Attar directly states that this love has been entrusted in the chest of our hearts from the beginning and man has been in love with his beloved before he entered the universe.

I wanted to offer my life to the victims, and he offered his love and my soul burned in it

(Attar, 1386: 18)

The front of love is much higher and higher than one can achieve it voluntarily. Love is a divine gift that they provide to whomever they want. Mystics sometimes consider this gift to precede the acceptance of human beings in the material world And sometimes it is called the heavenly judgment that "I was not yet the one who sat in my heart." Ahmad Ghazali says: "Because the soul was created from non-existence over the limit of existence, love was waiting for the compound of the soul" (Arjang Madi, 1372: 44)

Love is nothing but divine forgiveness. This is not to beg and beg

(Attar, 2007: 125/95)

The love of waqf on the painful heart of waqf is not a Baha'i in our sharia

(Same: 125)

God created man on the basis of love, and no creature other than man can follow in the footsteps of God in the way of love:

Love, because it was a human trait, to fall in love was to love

(Attar, 2007: 96)

In his poetic works, Jami has praised love among all mystical topics wherever he has the opportunity. He considers love to be an eternal gift on which human honor depends. In this regard, the author believes that perhaps love is the same trust that Jami accepted and others refused to accept. It is love that made God see in man such a capacity that he made him the manifestation of all his names and attributes. Jami has a special place for love and considers the dough to be the lifeblood of the beings as the essence of love:

Because the morning breathed love from the beginning, love burned the fire of passion in the pen

From the tablet of no pen, he raised a hundred endless original roles

They are the offspring of the love of the pillars of the earth

(Jami, 1987: 757)

Many people are drunk with the cup of love of God, but the first step of love, according to verse 54 of Surah Ma'idah, has been taken by God:

He said that the sheikhs are a group that holds his cup of air.

At first he loved them enough to plant them in his heart 
Do not understand this word unless you read Fasuf Yati Ella

Otherwise, he loved you. Who was your friend from the beginning?

(Jami, 1366: 250)

Jami believes that love is a divine grace that is specific to man, not angels:

What benefit did the angels have from the good obedience that the grace of love fell on Adam?

(Jami, 1987: 324)

Jami believes that man's love for God is a shadow of his love for man:

His love was the seed of our love and your first courtship

(Same: 250)

\section{Anger, rage and punishment}

Other themes in Attar and Jami's works include anger, rage and punishment; Anger is mentioned in Dehkhoda dictionary meaning anger, rage, anger, harshness, agitation. The findings of this theme were consistent with the findings of studies (Kapogiannis, Barbey, Su, Krueger, \& Grafman, 2009; Kapogiannis, Barbey, Su, Zamboni, et al. 2009; Kendler et al. 2003). The concept (Anger and Punish) was also expressed in those studies.

He said the truth is, where does this infidel constantly eat until now? ...

(Attar, 2006: 597)

Working on the anguish of my distressed one hundred blessings on my head

Fear, if you show me an obstacle, you will untie me a hundred knots from Raja

(Attar, 1385: 293)

In the story of three of the seventh articles of the tragedy, we see the tyranny of the kingdom that destroys the old house and God destroys the king in his palace with the prayer of the old man in pain:

He said, "If I was not here, oh my God, would you not be here?"

The Almighty destroyed that shah and buried him in his house

(Attar, 1385: 2037)

Fear, if you show me a hurdle, you will untie me a hundred knots from Raja

(Attar, 1385: 14)

One hundred thousand years of obedient collar curses the neck

(Attar, 1385: 3)

When the Almighty God deals with man with his anger and wrath, he still puts a hundred lights of grace in front of him:

If you warn of your torment, teach us a lesson soon. 
A dark path, come before me, a hundred lights, by your grace, come to me

(Attar, 1385: 18)

He was a scientist who was learning day and night about science and obedience to the truth. God sent a revelation to the Prophet of his time to tell him that because you are a worldly person, your knowledge has no effect and your place is nothing but my burning hell:

Because in the world, friendship does not accept the slightest right from you, what are you, you are proud

Because it is not far from the heart of the world, your place is nothing but burning hell One hundred worlds with knowledge and meaning to each other, hell, flour with the world (Attar, 2006: 146)

Concerning the contradiction between the names and attributes of the glory and beauty of God, it should be said that every grace of the Almighty is accompanied by His wrath and every wrath is by grace. Mystics and lovers of his door are not safe from fear and hope and acceptance and expansion for a moment, every fear is conceived by grace and every hope seeks the possessor of fear:

No one is in charge of you and you do everything you want Your gift does not prevent you from making a mistake, nor does it repel you.

(Jami, 1987: 6)

Jami has always felt the wrath of God with His servants in the system of existence and has even described the wrath of God in the other world:

He said that day when the veil of darkness was closed on their hearts and eyes Their knowledge and insight should be diminished and their religiosity should be bent.

(Ibid: 101)

Jami in Haft Aurang directly refers to the wrath of God that if God wants to deal with His servants in anger, they will disappear from the face of the universe altogether:

When he gets angry at a tomb, God will move it from its place

In a moment, the foundation of the foundation of the universe is laid.

(Ibid: 51)

\section{Guide}

Another theme found in this study was the Lord's control and guidance. Guidance in the word means guidance and guidance from grace and benevolence. Ragheb Esfahani says in the book "Mafradat": "Guidance in the word means guidance, guidance and showing the way with grace, tolerance and kindness." (Ragheb: 1404) This theme was similar to 
the findings of studies (Kay, Gaucher, McGregor, \& Nash, 2010; Krause, 2010), and in that paper, the concept (Control) was mentioned.

From the time of creation until the time of death, man has always been in contact with God. After creation and coming to the world of man, man is not left to himself, but God is always in charge of all matters of his life and communicates with man in the form of guidance. Jami believes in the absolute sovereignty of God; He believes that God has universal guidance and that this sovereignty will not be destroyed by interference. This kind of relationship with the creature, which is the result of his constant guidance to the Creator, is one of the definite forms of the agent and common relationship.

The Lord also helps and teaches man in times of trouble and calamity to see with the eyes of the heart the blessings hidden in times of trouble and calamity:

What is sugar? Ignore the part of the flower thorn, ignore the part, the whole idea

(Attar, 1386: 41)

It was a passion that escaped from the care of disbelief and guidance came

(Ibid: 63)

The Holy Prophet said: God created the angels and put only intellect in their nature, created animals and put only lust in their nature, created man and in his nature put both intellect and lust (Motahari, 1361) that Attar points out the religious intellect that is praised by him and is a kind of human guide from God:

The intellect must be called and the command of God to be both a leader and a guide

(Attar, 2006: 861)

From Jami's point of view, the guidance of God indicates a kind of permanent communication in which there is no change and no disruption. With this eternal decree, God has not severed his connection with man, and man has freed himself from any destiny by resorting to this pretext.

Jami believes that sometimes God comes to guide man through perfect human beings: His ancestor derived the source of guidance from such a source

(Jami, 1366: 155)

Electricity guided by the flame worm nebula ignited science upon science

(Same: 19)

And in his colorful week, Jami prays to the Lord and points to the Lord's connection through guidance:

Although it was a cup of the uninitiated, what if it were a parasite of others?

Part of his existence is news of his obedience to his waist 
In the heart of the seed of guidance on the flower of the cloud of light

(Same: 21)

\section{Forgiving}

Other concepts found in the relationship between man and God include the concept of being forgiving. Being forgiving in a certain culture means forgiving and merciful. This theme is in line with the findings of studies (Krause, 2010 and Froese \& Bader, 2007) in which studies of the relationship between man and God (Forgive) were discovered.

God's mercy and compassion includes all servants and beings. He is merciful and compassionate, and He loves His pious servants very much, and His general mercy includes even sinners, and if they repent, God forgives all their sins; God is the Holy Essence who has all-encompassing mercy and forgiveness on the servants of the believer and the disbeliever and provides for them. His vast mercy encompasses all beings. Rahman and Rahim are each similar attributes derived from the womb. The meaning of the Most Gracious is the general forgiveness of God, But his word is one of the special names of truth; That is, no creature other than God is called by this word. Rahman is the name of a sublime creator.

Although there is no forgiveness from comfort forgiveness because forgiveness

(Attar, 1385: 20)

Again the spirit of grace and forgiveness soon lifted Michael up

(Same: 40)

In the letter of tragedy, Attar, in the words of some who prayed for rain, refers to the Lord's connection through forgiveness:

Where is the sea of forgiveness of the trustee?

(Same: 3)

That I may have mercy on the worm as soon as the worm, although Alborz mountain (Jami, 1366: 250)

Around and Strength by the Grace of the Truth Flower of Wisdom from the Chine se Garden of Truth

Forgiveness is just a vision from God upon you.

(Ibid: 96)

Jami considers God to be forgiving and points to waiting for the forgiveness of sinners: I have come with all the pollution, waiting for forgiveness and forgiveness

(Same: 12) 
Servant of the cup that in increasing your eyes on your forgiveness and forgiveness

Forgive him and forgive him if you do not forgive him.

Safe from the hard of hell, resident in Naeem Karamesh

(Ibid: 54)

\section{Conclusion}

The relationship between God and man is evident in the works of Attar and Jami, very important concepts that are manifested in the universe, including the concepts of helping and protecting, love, anger, anger and punishment, controlling and guiding and being forgiving. It was shown that these themes can be used in order to advance knowledge and understanding of the essence of existence.

In general, the structure that Attar and Jami explained about the relationship between God and man shows the extent of the Creator's love for the creature and the sillyness of man's relationship with God in all moments of his life.

\section{References}

Buber, Martin (1398), Me and You, translated by Abu Torab Sohrab, Tehran: Farzan Rooz.

Tiwari, Kadarnat, (2002), Comparative Theology, translated by Marzieh Shankai, scientific edition by Behzad Saleki, first edition, Tehran: Organization for the Study and Compilation of Humanities Books.

Jami, Abdul Rahman (1366). Masnavi Haftavarang, edited by Modarres Gilani, Tehran: Saadi, second edition.

James, William (1387). Religion and psyche, translated by Mehdi Ghaeni. Qom: Dar alFikr

Khorramshahi, Bahauddin (1377). Memoirs, Tehran: Soroush Publications, Fourth Edition.

Al-Ragheb Al-Isfahani, Abi Al-Qasim Al-Hussein Ibn Muhammad (1404 AH). Vocabulary in the stranger of the Qur'an. Book Publishing Office.

Soroush, Abdolkarim, (2002), Tradition and Secularism, Tehran: Sarat.

Attar Neyshabouri, Farid al-Din Mohammad (1386). Tragedy letter, introduction, correction and comments of Dr. Mohammad Reza Shafiei Kadkani. Tehran: Sokhan, vol. 2, third edition

Attar Neyshabouri, Farid al-Din Mohammad, (2009), Misbatnameh, Introduction, correction and comments by Mohammad Reza Shafiei Kadkani, fifth edition, Tehran: Sokhan. 
Saremi, Soheila (1373), Mystical Terms and Prominent Concepts in Attar Language, First Edition, Tehran: Institute of Humanities and Cultural Studies.

Corbett, Lionel (2014), Religious Psychotherapy, Translated by Siamak Khoda Rahimi et al., First Edition, Tehran: Arad Ketab.

Mohammadi Riheshahri, Mohammad (1375), Fundamentals of Theology, first edition, Qom: Dar al-Hadith.

Madi, Arjang (1372). Love in Persian Literature from the Beginning to the Sixth Century, Second Edition, Qom: Institute of Research and Cultural Research.

Motahari, Morteza (1351), The purpose of life, first edition; Qom: Islamic Publications Office.

Motahari, Morteza (1361). Spiritual speeches. Tehran: Sadra.

Molavi, Jalaluddin Mohammad Balkhi (1379), Masnavi Manavi, by the efforts of Rinwald Nicholson, Tehran: Sales and Homay.

Jung, Carl Gustav (1370), Psychology and Religion, translated by Dr. Mohammad Hossein Sarvari; Tehran: Sokhan.

Izutsu, Toshihoko (1348), Non-Linguistic Relationship between God and Man, Islamic Studies, No. 8, pp. 62-51.

Researcher, Leila (2012). The relationship between God and man in theological and mystical literature with emphasis on the works of Rumi, Journal of Literary Studies, No. 22, pp. 124-97.

Zargaran, Iman (1398). God of Existential Unity and the images derived from it in Attar's poems, Scientific Journal of Poetry Research, Shiraz University, No. 3, Year 11, pp. 42-19.

Alam Mehrjerdi, Nasrin (1391). God's relationship with man; Representation, Incarnation or Manifestation ?, Volume 9, Number 28, pp. 30-5.

Ghazazni, Elham (1396). The Relationship between Man and God from the Viewpoint of Rumi, Asfar, Third Year, No. 6, pp. 132-111.

Sadeghi, Mansoura Sadat (1393). The Role of the Main Dimensions of Personality in the Type of Communication with God, Two Quarterly Journal of Islamic Studies and Psychology, No. 15, pp. 126-103.

Lotfi, Seyed Mehdi (2012), Revelation Communication Patterns, Journal of Comparative Theology, No. 7, pp. 100-79. 
Froese, P. \& Bader, C. D. (2007). God in America: Why theology is not simply the concern of philosophers. Journal for the Scientific Study of Religion, 46, 465481.

Kapogiannis, D. Barbey A. K. Su, M. Krueger, F. \& Grafman, J. (2009). Neuroanatomical variability of religiosity. PLoS ONE, 4 (9), e 7180. doi: 10.1371 / journal.pone.0007180.

Kapogiannis, D. Barbey, A. K. Su, M. Zamboni, G. Krueger, F. \& Grafman, J. (2009). Cognitive and neural

foundations of religious belief. Proceedings of the National Academy of Sciences of the U.S.A. $106,4876-4881$.

Kay, A. C. Gaucher, D. McGregor, I. \& Nash, K. (2010). Religious belief as compensatory control. Personality and

Social Psychology Review, 14, 37-48.

Krause, N. (2010) .God-mediated control and change in self-related health. The International Journal for the Psychology

of Religion, 20, 267-287.

Popp, C. A. Luborsky, L. Andrusyna, T. P. Cotsonis, G. \& Seligman, D. (2002). Relationships between God and people in the Bible: A core conflictual relationship theme study of the Pentateuch / Torah. Psychiatry: Interpersonal and Biological Processes, 65, 179-196.

WEINGARTEN, Carol P. et al. Relationships between God and people: an interpersonal study of scriptures. International Journal for the Psychology of Religion, 2014, 24.2: $133-150$. 